4 Kalmár $\mathrm{Zs}$, Czeizel A. The analysis of preventive programme of neural tube defects. Orvosi Hetilap 1980;:1205-12. (In Hungarian.)

5 Béres J, Czeizel A. The frequency of prenatal chromosome analysis in pregnan women over 40 in Hungary. Orvosi Hetilap 1988;129:529. (In Hungarian.)

6 Czeizel A, Métneki J, Osztovics M. Evaluation of information-guidance genetic counselling. F Med Genet 1981;18:91-8.

7 Czeizel A, Métneki J. Evaluation of counselling for pregnant women exposed to potentially hazardous environmental factors. Acta Paediat Hung 1985;26:175-86.

8 Congenital malformations worldwide: a repon from the International Clearinghouse for Birth Defects Monitoring Systems. Amsterdam: Elsevier, 1991.

9 Woolf CM, Koehn JH, Coleman SS. Congenital hip disease in Utah: the influence of genetic and nongenetic factor. Am f Hum Genet 1968;20:430-9.

10 Smithells RW, Sheppard S, Wild J, Schorah CJ. Prevention of neural tube defect recurrences in Yorkshire: final report. Lancet 1989;ii:498-9.
11 MRC Vitamin Study Research Group. Prevention of neural tube defects: result of the MRC vitamin study. Lancet 1991;338:131-7.

12 Czeizel A. Prevention of the first occurrence of neural tube defect. Results of the Hungarian randomised controlled trial of periconceptional multivitamin supplementation. N Engl $\mathcal{F}$ Med 1992;327:1832-5.

13 Luck CA. Value of routine ultrasound scanning at 19 weeks: a four year study of 8849 deliveries. $B M$ I $^{1992 ; 304: 1474-6 .}$

14 Sheldon TA, Simpson J. Appraisal of a new scheme for prenatal screening fo Down's syndrome. BMF 1991;302:1133-6.

15 Wald NJ, Kennard A, Densem JW, Cuckle HS, Chard T, Butler L. Antenata maternal serum screening for Down's syndrome: results of a demonstration project. $B M \Im$ 1992;305:391-4.

(Accepted 30 October 1992)

\title{
Health care in Brazil
}

\author{
Andy Haines
}

Brazil has great geopolitical importance because of its size, environmental resources, and potential economic power. The organisation of its health care system reflects the schisms within Brazilian society. High technology private care is available to the rich and inadequate public care to the poor. Limited financial resources have been overconcentrated on health care in the hospital sector and health professionals are generally inappropriately trained to meet the needs of the community. However, recent changes in the organisation of health care are taking power away from federal government to state and local authorities. This should help the process of reform, but many vested interests remain to be overcome. A link programme between Britain and Brazil focusing on primary care has resulted in exchange of ideas and staff between the two countries. If primary care in Brazil can be improved it could help to narrow the health divide between rich and poor.

Brazil has often been in the news because of the impeachment of President Collor, the Rio conference, widespread concern about environmental issues ${ }^{1}$ and violence, including the murder of street children, and, most recently, prisoners in Sao Paulo. ${ }^{2}$ Much less has been written about the organisation of health care in the country. Brazil is a country of contrasts. These are exemplified in the health sector by gleaming tertiary care and research institutes in major cities such as Sao Paulo and poorly equipped or absent health posts in the

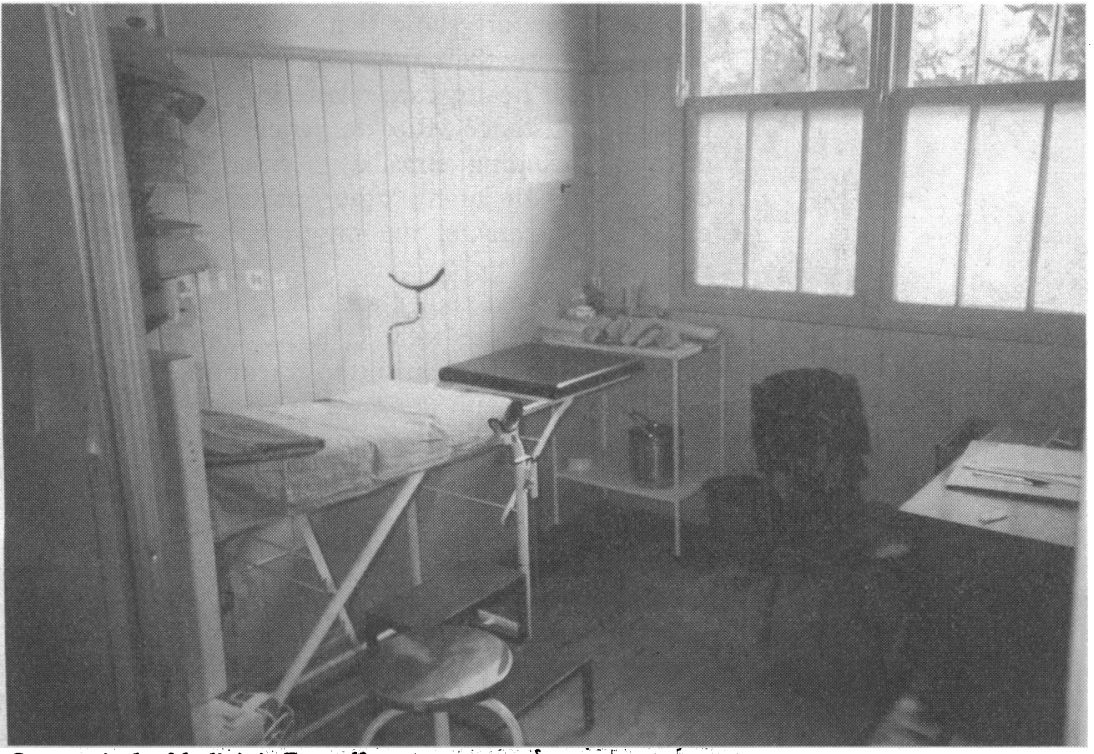

ubiquitous shanty towns (favelas). Brazil has a heavy burden of international debt, which is a major contributor to its economic and health problems, ${ }^{3}$ but wealth is also characterised by striking internal divisions. The top $20 \%$ of the population have 26 times the income of the bottom $20 \%$, one of the largest differentials in the world. ${ }^{4}$ The statistics given in the table illustrate some of the schisms in Brazilian society.

Comparison of health and wealth in Brazil with other countries with medium human development

\begin{tabular}{|c|c|c|c|}
\hline$\cdot$ & Year & Brazil & $\begin{array}{l}\text { Average for } \\
\text { medium }{ }^{\star} \text { human } \\
\text { development } \\
\text { countries }\end{array}$ \\
\hline Infant mortality (per 1000 live births) & 1990 & 60 & 40 \\
\hline $\begin{array}{l}\text { Under } 5 \text { mortality (per } 1000 \text { live } \\
\text { births) }\end{array}$ & & & 55 \\
\hline$\%$ Of children immunised at 1 year & $1988-90$ & 83 & 89 \\
\hline$\%$ Of mothers breast feeding at 1 year & $1980-90$ & 34 & 45 \\
\hline $\begin{array}{l}\% \text { Of children under } 5 \text { underweight } \\
\text { Maternal mortality (per } 100000 \text { live }\end{array}$ & $1980-90$ & 7 & 20 \\
\hline births) & 1988 & 230 & 170 \\
\hline Population per doctor & 1984 & 1080 & 1500 \\
\hline Population per nurse & 1984 & 1210 & 1540 \\
\hline Public expenditure on health $(\%$ of & & & \\
\hline GNP) & 1987 & 1.7 & 1.5 \\
\hline $\begin{array}{l}\% \text { Completing primary education } \\
\text { Tertiary education enrolment }\end{array}$ & 1988 & 20 & 74 \\
\hline $\begin{array}{l}\text { Tertiary education enrolment } \\
\text { rate }(\%) \\
\text { Public expenditure on education }\end{array}$ & $1988-9$ & 11 & 6 \\
\hline $\begin{array}{l}(\% \text { GNP) } \\
\text { Televisions per } 1000 \text { people } \\
\text { GNP per capita (US\$) }\end{array}$ & $\begin{array}{l}1989 \\
1988-9 \\
1989\end{array}$ & $\begin{array}{l}3 \cdot 7 \\
204 \\
2500\end{array}$ & $\begin{array}{l}3 \cdot 8 \\
64 \\
924\end{array}$ \\
\hline
\end{tabular}

GNP = gross national product.

*Defined as a country which has a human development index (HDI) of $0 \cdot 500-0 \cdot 799$. The index is a measure of development devised by the $U N$ Development Programme. It includes three key components: longevity, knowledge (audit literacy and mean years of schooling), and income. These are combined in a three step process to form an average deprivation index with a maximum value of 1.0 .

The death rates in infants and children under 5 are higher than in countries of equivalent development. The number of televisions per 1000 people is three times higher. Although the ratio of doctors to nurses is high most of the population have poor medical facilities.

\section{Organisation of health care}

Until 1987, there were entrenched divisions in the organisation of health care. Curative treatment and medical care were the responsibility of the social security ministry agency Instituto Nacional de Assistencia Medica Previdencia Social. Care was provided by units run by the agency and accredited private services. Preventive activities and communicable diseases were the responsibility of the health minister and state health secretariats, which ran health centres, public health laboratories, and hospitals specialising in transmissible diseases. In 1988 Brazil 
decided to set up a unified and decentralised health system and this process is now under way.

In the new system the health ministry has sole federal responsibility for health care but will be less involved in the delivery of health care. The health secretariats in each of the states will coordinate health care and the local authorities (municipalities) will run local facilities. This transition, however, is fraught with problems, including reluctance of authorities to devolve power and money and the difficulty state and municipal governments have in working together if they are controlled by different political parties. Unless a consensus can be developed about priorities, health care may become a political football, with programmes being terminated by incoming administrations merely because they were introduced by an opposing party. There is also a danger that the reforms will enshrine the division between primary, secondary, and tertiary care and make it difficult to coordinate their activities and to move funds from one sector to another.

In addition to public funding, much health care is financed privately by both companies and individuals. Though the rich spend much more than the poor on health care, the poor spend a much greater proportion of their income (about 5\% v 2\%). ${ }^{5}$ The rich tend to buy the services of doctors and the poor purchase mostly unprescribed medicines from pharmacists. Privately financed and provided group medical plans are assuming greater importance. A monthly capitation fee is paid to profit making companies. Doctors' cooperatives are being formed which seek to prevent exploitation of doctors, but because of this care may be more expensive than that provided by group medical plans. The box describes the effects of the health divide.

A considerable amount of the care (around $80 \%$ in 1991) funded from public sources is provided in private hospitals. Construction of private hospitals was boosted by financial incentives during the period of economic growth in the 1970s. The average costs of treating patients at private hospitals are less than those in public hospitals. This is partly because private hospitals select simpler cases but may also reflect the lack of incentives to reduce admissions and length of stay in public hospitals and the absence of adequate community care for the impoverished populations which tend to use them. The cost per admission varies in both private (nearly twofold) and public hospitals (over fourfold). It has been suggested that the lack of control over the system of payment by the Ministry of Health has created "monumental distortions and fraud." Physicians in public service often have several

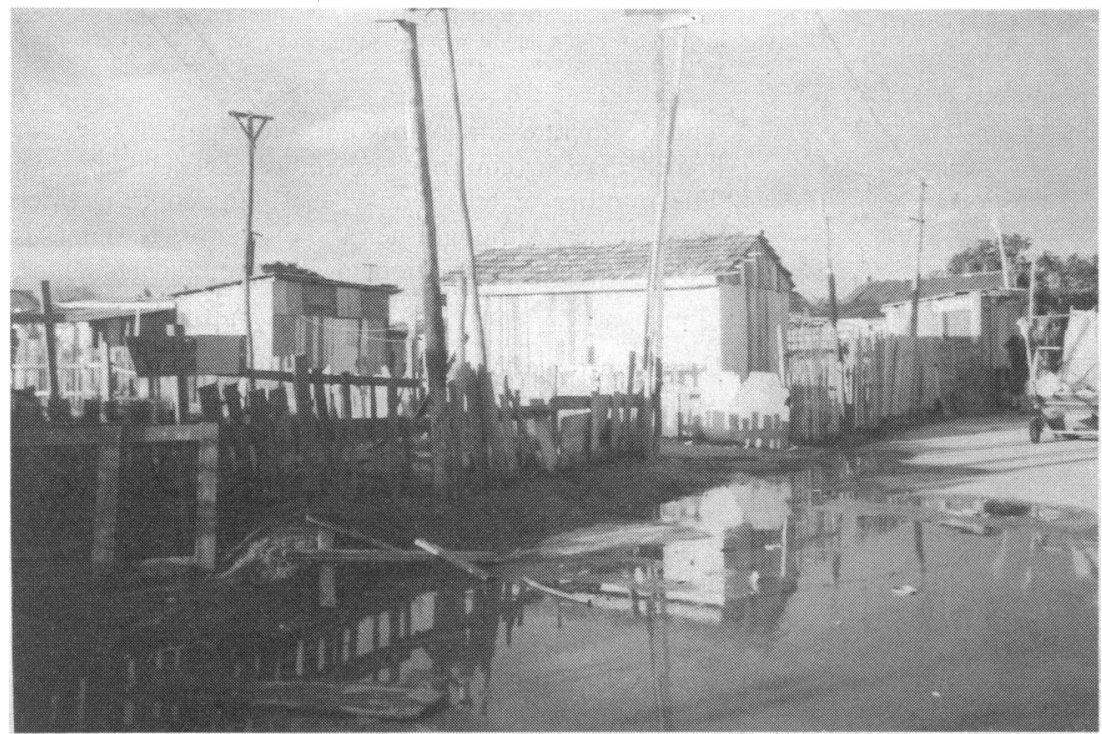

Favelas house Brazil's poorest citizens

\section{Health divide}

The patterns of disease differ among the poor, particularly in the north and the slums of the large cities, and the rich. Overall, deaths from infectious and parasitic diseases have fallen steadily from $45 \%$ of the total in 1930 to about $11 \%$ in 1980 , while deaths from cardiovascular diseases, cancers, and injuries have risen steadily. Thus in many parts of the country there has been a transition from a pattern of high infant and communicable disease mortality typical of a developing country to that found in many developed countries.

Compared with countries that have similar life expectancy, cardiovascular death rates are unusually high in developed parts of Brazil. In Sao Paulo, for instance, hypertension is an associated cause of death in about $30 \%$ of adults. 5 AIDS is a growing problem, and about $20 \%$ of people with AIDS are classified as bisexuals. The prevalence of HIV infection in men who define themselves as bisexual is as high as that in homosexual men. The prevalence of the virus in female prostitutes who do not use drugs is higher than in the United States and as high as that in African prostitutes in the early 1980 s. $^{6}$ High rates of accidental death are apparently due to a combination of drinkdriving and inadequate traffic regulations or their enforcement.

In the states of the north and north east tropical diseases are common and mortality in under $5 \mathrm{~s}$ is still high. In recent years garimpeiros (gold miners) and loggers have made major incursions into virgin forests, sometimes threatening the survival of Indian tribes such as the Yanomami and resulting in many health problems such as sexually transmitted diseases and malaria. ${ }^{7}$ Schistosomiasis, Chagas' disease and leishmaniasis are also important problems, particularly in the north. ${ }^{89}$

According to United Nations projections, the population (currently around 150 million) will reach around 245 million by 2025 . Already, $75 \%$ of the population is urban. The average population growth rate is $1.9 \%$, similar to that of Latin America as a whole. The urban growth rate is projected as $2.7 \%$ between 1990 and $1995 .^{10}$

jobs to provide an adequate income. This means the time they spend in the public sector is often much less than that for which they are contracted. They are often inappropriately trained to provide general primary medical care.

Brazil's ninth national conference on health in August 1992 was an important opportunity to discuss the movement towards decentralisation and democratisation of health care and had as its motto "municipalisation is the only way." Figures presented in the conference report show that some states have been receiving more than their fair share of government resources for health care taking into account population. For instance, Rio de Janeiro and the federal district (including Brasilia) seemed well resourced compared with many other parts of the country, particularly many of the impoverished states of the north east. ${ }^{12}$

The conference took place at a time of great political turmoil, and there were calls for the resignation of President Collor and an end to corruption. Many of the proposals dealt with the need to ensure that resources reached their intended destination and that they were augmented by the creation of new taxes on industrial and agricultural sectors. The mood was exciting and sometimes emotional, with secretaries of health from many towns around the country participating. Improving health care is clearly a priority for many local politicians - for instance, eight of 12 successful candidates for the city council in Rio de Janeiro mentioned health when asked about their priorities by the newspaper fornal do Brasil. 


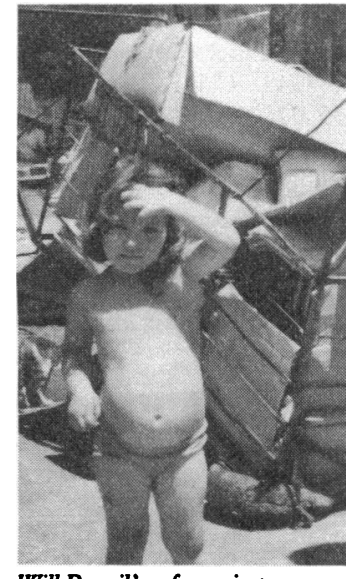

Will Brazil's reforms improve her health care?

\section{Link programme}

One of the key priorities for Brazil is to develop primary care in a system which has been completely dominated by hospital based medicine. Demands for health care are likely to increase because of factors such as the aging population, the spread of HIV, and rising expectations. Over the past three years my department has been collaborating with a training programme for general practitioners based at the Conceicao Hospital in Porto Alegre, a large city in the southernmost state of Rio Grande do Sul with a population of around 1.5 million. Although the city compares favourably with other parts of Brazil in socioeconomic terms, there are areas of great poverty, particularly in favelas, many of which are inhabited by people moving from the countryside because of lack of employment and inequalities in land tenure.

Some years ago the British Council identified primary care as one of the priorities for development of a link programme between Britain and Brazil. Porto Alegre was identified because it has two of the very few general practice training programmes in the country. The Conceicao programme produces about 15 general practitioners a year from a two year training programme (a third year is optional). Training is given by experienced practitioners, many of whom have been through the programme. Physicians trained in internal medicine are attached and function as consultants.

Unlike many of their colleagues in the public sector general practitioners in the Conceicao programme work for the full contracted eight hours a day. The Conceicao programme has a few hospital beds but its main functions are to run community health centres in favelas and a large primary care clinic in the main hospital which caters for the local population. The programme has closer links with the community than many general practitioners in Britain and works closely with local resident groups. Although it is hampered by a lack of trained community nurses, it has undertaken a process of community diagnosis to determine local health problems ${ }^{1314}$ and conducts numerous preventive and health education activities, including cervical cytology programmes, visits to schools, group work with mothers, and the training of health agents.

Health agents are members of the local community who are trained to provide preventive and simple curative care as members of the primary care team. In addition, general practitioners sometimes act as advocates for the community, meeting with local officials to try to promote improvements in sanitation and basic infrastructure. Whether doctors should concentrate solely on the clinical aspects of general practice or act in a wider capacity to tackle the underlying causes of ill health is a subject often discussed. Preliminary data from a recent audit exercise have shown that uptake of immunisation has improved from $60 \%$ in 1986 to $90 \%$ in 1991 (S Takeda, A Stein, M Costa, personal communication).

The link programme has also developed contacts with one of the three medical schools in the city, the faculty of medicine of the Federal University of Rio Grande do Sul. It operates from a large teaching hospital which until recently had no community links. Undergraduate students have begun to recognise the importance of primary care. An increasing number of them come to work with the general practitioners in the Conceicao programme for up to one month on a voluntary basis during their holidays. Some go to other health centres including one at Vila Cruzeiro, a large favela community that has links with the department of social and preventive medicine. The long term hope is that academic general practice will be developed in the faculty of medicine.

\section{Exchange of staff}

The role of the link programme is to promote an exchange of ideas and has led to visits in both directions. Several Brazilian doctors have completed MSc degrees in Britain. Research projects, particularly in qualitative research, have been set up following visits by Cecil Helman, a general practitioner and medical anthropologist. These studies have focused on problems identified by Brazilian colleagues, including poor compliance with immunisation and other preventive measures, poor attendance at antenatal clinics, problems with the role and training of health agents, and the high rate of somatisation. Elaine Fullard from Oxford, who has been influential in developing the role of nurse facilitators for prevention in primary care, and Anita Berlin from St Mary's Medical School, who has a particular interest in teaching communication skills, have also been to Brazil as part of the programme.

In October last year I was able to visit Fundacao Esperanca (Hope Foundation), which has developed a comprehensive training and support programme for health workers from villages along the Amazon and Tapajos rivers. It has a well organised base clinic in Santarem, a city of around 250000 at the junction of the two rivers. This provides medical, laboratory, and nursing back up for the village outreach programme and deals with health problems of local townspeople. It also uses volunteer specialists, some recruited locally, but many coming from abroad on short visits. In particular, they need surgeons and anaesthetists, pathologists, laboratory technicians, and teachers of health care and nursing (for address see below). The clinic intends to focus in future on training local health professionals, community health workers, and planners for the process of "municipalisation" of health care.

\section{The future}

A conference will be held in May in Porto Alegre to promote the process of decentralisation of health care in Brazil. It will bring together interested parties from around the country to exchange experience and to develop a network for interested individuals, educational institutions, training programmes, and state administrations. This is being undertaken under the auspices of Action in International Medicine, an organisation based in London which has the support of around 100 colleges and academies of medicine and allied health professions in over 30 countries (for address see below). It is being organised in conjunction with several Brazilian institutions including the health secretariat of the municipality of Porto Alegre, the State Secretariat of Health of Rio Grande do Sul, the faculty of medicine of the Federal University of Rio Grande do Sul, and the National Council of Municipal Secretaries of Health.

The growing role of municipalities in providing health care means that there is bound to be more emphasis on primary care. Some states, such as that of Ceara in the north east, have taken radical steps. The governor has authorised recruitment of 4000 women, many of them already lay midwives, to act as health agents, applying Unicef procedures. Infant mortality has already been reduced by $32 \%$. In order to fund this process hospital building has been cut back. ${ }^{15}$

Although for primary care to be effective in Brazil it must be allied to community development and participation and include non-professional health workers, health professionals have useful roles. Brazilian medical schools have little commitment to training doctors for the health needs of the community as most will become specialists. Once career opportunities exist for general practitioners there will be 
more pressure on medical schools and postgraduate institutions to give appropriate training. The Brazilian Society of Community and General Doctors is seeking to address this situation and could act as a catalyst, advocate, and pressure group, as well as promoting good quality training, just as the Royal College of General Practitioners has done in this country.

It is difficult to evaluate the effectiveness of the link programme, but we believe it has helped to broaden the perspective of both the British and the Brazilian particiants. By providing an outside point of reference for the important work being undertaken by our Brazilian colleagues it has helped to give community based approaches to health care credibility within the country. This is important because there are many interests which may try to stifle attempts to improve health care.

Potentially far reaching changes are occurring in Brazilian society and the health care system has become a focal point for change. If the forces unleashed are sufficient to overcome bureaucratic inertia and corruption they could bring about a transformation which will have even greater impact and importance than the development of the NHS in Britain. If they fail, the rapidly growing populations in the favelas of the great urban centres will become even more desperate in their quest for survival, with incalculable consequences for the stability and future of the country. The potential for large population movements to wreak havoc on environmentally vital regions such as the Amazon basin means that the outcome of the struggle for health and development in Brazil is of international importance.
I thank Drs Airton Stein, Magda Costa, and Silvia Takeda for help in preparing this article. The address of Fundacao Esperanca is: Ronald Bertagnoli, Director, Fundacao Esperanca, Rua Coaracy Nunes, 3344, Caixa Postal 222, Santarem, Para, Brazil, fax: 0105591522 7878, tel: 01055 91522 2726. The address of Action in International Medicine is: Windeyer Building, 46 Cleveland St, London W1P 6DB.

1 Mendes C. Fight for the forest. London: Latin America Bureau, 1989

2 Brazil's worst prison massacre: 111 die. $B M \mathcal{F}$ 1992;305:909-10

3 Logie D. The great exterminator of children. $B M$ J 1992;304:1423-6.

4 United Nations Development Programme. Human development report 1992. Oxford: Oxford University Press, 1992.

5 World Bank. Adult health in Brazil: adjusting to new challenges. Washington, DC: World Bank, 1989. (Report No 7807-BR.)

6 Cortes E, Detels R, Aboulafia D, Xi LL, Moudgil T, Alam M, et al. HIV-1, HIV-2, and HTLV-1 infection in high risk groups in Brazil. New Engl f Med 1989;320:953-8.

7 Marsden P. Growing problem of malaria. BMf 1989;299:1328-9.

8 Marsden PD. Fertile flukes and mediating molluscs. BMF 1990;300:31 1-2.

9 Marsden PD Leishmaniasis. BM7 1990; 300:666-7.

10 State of the world's population. New York: United Nations Population Fund, 1992

11 de Oliveira Jr M. Problemas atuais e proposta para a revisao da politica de financiamento do sistema unico de saude no Brasil. In: IX Conferencia Nacional de Saude, Cadernos da Nona. Vol 2. Brasilia: Cultura Grafica Editora, 1992.

12 Vianna SM, Piolo SF, Guerra AJ, Camorgo SF, Mandell MJ, Alumes da Silva JA. O financiamento da decentralizacao dos servicos de saude, criterios para transferencias de recursos federais para estados e municipios-summario executivo. In: IX Conference Nacional de Saude, Cadernos da Nona. Vol 1. Brasilia: Culture Grafica e Editora, 1992

13 Stein A, Reolon MGP, Busetti MC, Takeda S. Metodo de avaliacao de um servico de medicina geral communitaria. I. Diagnostico de saude da comunidade. Momento e Perspectiva de Saude-Poro Alegre 1987;1:60-4

14 Busetti MC Stein A, Albuquerque MA, Takeda S. Metodo de avaliacao de um servico de medicina geral comunitaria. II. Diagnostico de demanda. servico de medicina geral comunitaria. 11. Diagnos

15 Rocha J. Small time plans lift Brazil's poor. Guardian 1991 September 14:7.

\title{
Lesson of the Week
}

(Accepted 1 December 1992)

\section{Arsenic and mercury intoxication due to Indian ethnic remedies}

\author{
John Kew, Catherine Morris, Avan Aihie, Raymond Fysh, Sarah Jones, David Brooks
}

\section{Ethnic remedies} prescribed by hakims may contain toxic amounts of arsenic and mercury

Department of Neurology, Hammersmith Hospital, London W12 0HS John Kew, research fellow Catherine Morris, senior house officer

David Brooks, consultant neurologist

Poisons Unit, Guy's Hospital, London SE1 Avan Aihie, registrar

Metropolitan Police Forensic Science Laboratory, London Raymond Fysh, forensic toxicologist

\section{St Andrew's Hospital,} London

Sarah Jones, senior house officer

Correspondence to: Dr J Kew.
We have recently seen two cases of heavy metal intoxication resulting from ingestion of Indian ethnic remedies. The substances were dispensed by an Indian ethnic practitioner, or hakim, as a treatment for eczema and were found to contain toxic amounts of inorganic arsenic and mercury.

\section{Case 1}

A 35 year old Asian man presented with a three month history of progressive weakness of his hands and legs associated with distal sensory disturbance. The patient had first become aware of the symptoms six weeks after a hakim had started treating him for atopic eczema.

On examination Mees' lines were present in the finger nails and there was hyperkeratosis of the soles of the feet. Symmetrical wasting and weakness was present in the upper and lower limbs and all tendon reflexes were absent. Cutaneous sensation was impaired in a glove and stocking distribution. He could not stand from a sitting position without using his arms and walked with difficulty unsupported.

Electromyography suggested a peripheral sensorimotor neuropathy. The presence of a raised urinary concentration of inorganic arsenic $(63 \mu \mathrm{g} / \mathrm{l}$; normal $<2 \mu \mathrm{g} / \mathrm{l}$, toxic concentration $>2 \mu \mathrm{g} / \mathrm{l}$ ) and a hair arsenic concentration of $20 \mu \mathrm{g} / \mathrm{g}$ on $x$ ray fluorescence spectrometry (normal $<1 \mu \mathrm{g} / \mathrm{g}$ ) confirmed arsenic intoxication.

Samples of the ethnic remedies obtained from the hakim were analysed by flameless atomic absorption spectrophotometry and $x$ ray diffraction analysis (table). Packets of the mixed white and orange-brown powder most strongly implicated in this case each contained an average of $105 \mathrm{mg}$ of inorganic arsenic trioxide $\left(\mathrm{As}_{2} \mathrm{O}_{3}\right)$. The patient had been told to take two packets daily.

Chelation therapy with 2,3-dimercapto-1-propansulphonic acid (DMPS) $100 \mathrm{mg}$ three times daily for three weeks and later dimercaptosuccinic acid (DMSA) $400 \mathrm{mg}$ three times daily for two weeks was given without objective improvement in muscle strength. Two years after the onset of symptoms the patient was still unable to return to work.

Composition of Indian ethnic remedies found in the possession of the hakim. The preparation principally responsible for each case of poisoning is indicated in italics

\begin{tabular}{|c|c|c|}
\hline Description & $\begin{array}{c}\text { Main } \\
\text { constituent(s) }\end{array}$ & $\begin{array}{l}\text { Average content } \\
\text { per preparation* } \\
\text { (mg) }\end{array}$ \\
\hline $\begin{array}{l}\text { Mixed white, orange, and } \\
\text { brown powders (case 1) }\end{array}$ & $\begin{array}{l}\text { Arsenic trioxide } \\
\text { Mercuric sulphide } \\
\text { ("cinnabar") } \\
\text { Strychnine }\end{array}$ & $\begin{array}{l}105 \\
\\
654 \\
0 \cdot 7\end{array}$ \\
\hline Deep red powder & $\begin{array}{l}\text { Arsenic trioxide } \\
\text { Mercuric sulphide }\end{array}$ & $\begin{array}{c}90 \\
550\end{array}$ \\
\hline $\begin{array}{l}\text { Beige pills } \\
\text { Red-brown pills (case 2) } \\
\text { Brown-black solid }\end{array}$ & $\begin{array}{l}\text { Arsenic trioxide } \\
\text { Mercuric sulphide } \\
\text { Mercuric chloride } \\
\text { Mercurous chloride } \\
\text { ("calomel") }\end{array}$ & $\begin{array}{c}30 \\
30-42 \\
34 \\
160\end{array}$ \\
\hline
\end{tabular}

*In the case of powders "preparation" refers to a quantity of powder contained in a paper package intended to be taken as a single oral dose. 